\title{
Analysis of Children's Primary School Readiness According to Some Variables
}

\author{
Yalçın Bay ${ }^{1}$, Dondu Neslihan Bay ${ }^{2}$ \\ ${ }^{1}$ Anadolu University/Education Faculty, Turkey \\ ${ }^{2}$ Eskisehir Osmangazi University/Education Faculty, Turkey
}

\begin{abstract}
The aim of this study was to determine the primary school students' readiness for school and analyze it according to some socio-demographic characteristics. Furthermore, the research will contribute in terms of revealing how much the children are ready to begin the process of elementary school in Turkey, which has a different education system and culture. The research was conducted in the general survey model, one of the quantitative research methods and 402 children attending the first grade of primary school in Eskisehir province participated in the study. In the study, "Primary School Readiness Scale" (Canbulat and Kırıktaş, 2016) was filled by teachers for each child. Children's readiness for school was analyzed in cognitive, affective, psychomotor and self-care skills sub dimensions of the scale. As a result of the research, it was found that primary school readiness levels of the following children groups were significantly higher $(\mathrm{p}<0.05)$ : the children who had preschool education compared to the children who had not; the children who are 72-84 months old compared to the children who are 60-72 months old; the, children whose mothers' education level are high compared to the children whose mothers have lower education and the children whose fathers are working compared to the children whose fathers are not working. In addition, significant differences were found in primary school readiness level of some subgroups in the following dimension: girls are significantly more ready in affective dimension; the readiness of the children whose mother is working is higher in cognitive dimension; and children whose father had university education and more are more ready in cognitive, affective and psychomotor dimensions $(\mathrm{p}<0,05)$.
\end{abstract}

Keywords: School readiness; preschool; primary school; cognitive; affective

\section{Introduction}

The period in which the child starts primary school is seen as an important milestone in the life of the child. If the child had not received pre-school education, he/she starts to receive education from adults other than their peers and family for the first time. This change in the child's life can lead to consequences where he/she can achieve or fail to fulfill the tasks and responsibilities. The positive or negative experiences of the child who started primary school play an important role in achieving a productive life of education. The key concept for a good beginning and continuation as successful and happy individuals is expressed as readiness. 
This research aims to reveal the primary school readiness of the children in Turkey and the effect of some variables on the readiness level.

Readiness, which is also expressed in different terms such as school maturity, preparedness (Erkan \& Kirca, 2010), is defined as the language and thinking skills that the child should have before starting school, as well as the skills required for adaptation and success (Noel, 2010). These skills are the skills that show that the child matured in terms of emotional, social, physical and cognitive development areas that should be possessed before starting school (Gündüz and Çalışkan, 2013; Yörükoğlu, 1993). The child, who is ready for school, gets sufficient development with the support of family, environment and school and possesses the necessary knowledge, skills and behaviors (Dinç, 2013). Hence, in addition to the developmental characteristics, there are some factors that affect the child's school readiness, such as family and environmental conditions (Stocks \& Oshio, 2009). Regarding school readiness, several researches focusing on the gender and age variables of the child were found (e.g., Arı \& Özcan, 2014; Erkan \& Kırca, 2010; Öztürk \& Uysal, 2013; Yoleri \& Tanış, 2014) and these studies revealed a positive relationship between school readiness and the increase in the age of the child (e.g., Vandell, Nenide, \& Winkle, 2006). In Turkey, the child's chronological age is considered as the basic criteria to start primary school (Canbulat and Y1ldizbaş, 2014). After it has been decided that the duration of primary school education will be 4 years in the 2012-13 academic year, the age range of starting primary school has been set as 60-66 months (MoNE, 2012). However, it was possible to postpone schooling for up to 71 months with a doctor's report indicating that the child was not developmentally ready for school (Başbuğ \& Kurnaz, 2013; Canbulat \& Yıldızbaş, 2014). Researches showed that children who have started primary school according to chronological age have problems in terms of school readiness (e.g., Canbulat, 2010; Öztürk \& Uysal, 2013). Considering these problems, the age of starting primary school was changed in 2019 after the decision taken by the Ministry of National Education and the upper limit was changed to 69 months (MoNE, 2019).

Another variable that has a significant effect on the child's school readiness level is preschool education (Koçyiğit \& Saban, 2014; Yavuzer, 2010; Yoleri \& Tanış, 2014). In Turkey, all children are expected to receive pre-school training. Planned and systematic pre-school education aiming to support children's developmental areas and to improve their skills plays an important role in the child's primary school readiness level (Ayhan and Aral 2007; Umek, Kranjc, Fekonja, \& Bajc, 2008). According to the researches, it is seen that in terms of basic skills and development areas, children having preschool education have higher level of school readiness compared to children without preschool education. (e.g., Cinkılıç, 2009; Erkan and Kırca, 2010; Esaspehlivan, 2006; Işık, Akosmanoğlu and Bilir, 2015; Magnuson, Meyers, Ruhm and Waldfogel, 2004; Unutkan, 2003; Yazıc1, 2002; Yoleri and Tanis, 2014). Polat and Yavuz (2014) reported that the duration of pre-school education increases children's selfesteem, self-concept, mathematical skills, drawing skills, phonological skills, social-emotional development and cognitive-linguistic development. Since the preparation to primary school requires the systematic acquisition of necessary skills and supporting all development areas of the children (Oktay and Unutkan, 2005), preschool education is an important opportunity to be used for the school readiness of disadvantaged children (Polat \& Yavuz, 2016; Umek et al., 2008). 
Families have a significant effect on the children's school readiness as much as Preschool education. The behaviors and attitudes of the family towards the child are quite effective in making the child ready for education life (Akbag, 2007). The family must fulfill its responsibilities to ensure that the child will be ready for school from the moment of birth (Dinç, 2013). Socio-economic conditions of families may affect to provide effective environments for children, and the socio-economic status of the family is determined by the working status of the parents. Working parents have higher income and therefore can live under better conditions. A supportive home environment, which can be established with better economic conditions, affects the child's primary school readiness significantly (Britto, 2012; Ferguson, Bovaird and Mueller, 2007). Isaac and Magnuson (2011) concluded that there was a positive relationship between the increase in the economic conditions and educational levels and school maturity of the child. The increase in the education level of the family also positively affects children's school readiness (Alakoç Pirpir et al., 2016; Erkan, 2011; Erkan \& Kirca, 2010). The research conducted by Ar1 and Özcan's (2014) on the effect of school maturity on the literacy learning of first-year pupils revealed that the increase in the educational level of the parents increased reading maturity in children.

Starting primary school is an important event that requires the child to be ready for education life and some factors have an impact on the readiness of the child. The child who starts primary school should be supported in case of deficiencies or inadequacies. This support is only possible by determining how much the child is ready for primary school. This research is considered to be important in terms of revealing the extent of the children's primary school readiness and the factors that affect the readiness levels.

\section{Goal of the Research}

The objective of the study was to determine school readiness levels of first-year pupils and to analyze it according to some socio-demographic characteristics. In line with this objective, the following sub-objectives were also addressed in addition to determining overall school readiness of first-year pupils: revealing the differentiation of first-year pupils' school readiness in terms of pre-school education, gender, age, educational level and working status of their parents.

\section{Method}

This research is based on relational screening model, which is a research model that identifies the existence and/or the degree of the change between two or more variables (Karasar, 2016). In this study, the relational screening model was used to determine whether children's school readiness differed according to their pre-school education, gender, age, and educational and working status of their parents.

\section{Participants}

In this study, preschool teachers working in independent kindergartens in Eskişehir were determined as the universe of the study. The sample of the study consists of 402 children, studying in the first year of primary school in the central districts of Eskişehir. The table showing the demographic information of the participants is given below; 
Table 1. Demographic Information

\begin{tabular}{|c|c|c|c|}
\hline \multicolumn{2}{|c|}{} & $\mathrm{N}$ & $\%$ \\
\hline \multirow{2}{*}{ Preschool Education } & Had Preschool Education & 374 & $93.0 \%$ \\
\cline { 2 - 4 } & Didn't have Preschool Education & 28 & $7.0 \%$ \\
\hline \multirow{2}{*}{ Gender } & Female & 199 & $49.5 \%$ \\
\cline { 2 - 4 } & Male & 203 & $50.5 \%$ \\
\hline \multirow{2}{*}{ Age } & 6 years-old & 278 & $70.6 \%$ \\
\cline { 2 - 4 } & 7 years-old & 118 & $29.4 \%$ \\
\hline \multirow{3}{*}{ Mother's Education } & Primary School & 79 & $19.7 \%$ \\
\cline { 2 - 4 } & Secondary School & 88 & $21.9 \%$ \\
\cline { 2 - 4 } & High School & 117 & $29.1 \%$ \\
\hline \multirow{2}{*}{ Mother's Employment status } & University, Postgraduate & 118 & $29.4 \%$ \\
\cline { 2 - 4 } & Housewife & 254 & $63.2 \%$ \\
\hline \multirow{3}{*}{ Father's Education } & Employed & 148 & $36.8 \%$ \\
\cline { 2 - 4 } & Primary School & 35 & $8.7 \%$ \\
\cline { 2 - 4 } & Secondary School & 12 & $17.9 \%$ \\
\cline { 2 - 4 } & High School & 133 & $30.3 \%$ \\
\hline \multirow{2}{*}{ Father's Employment status } & University, Postgraduate & 16 & $4.1 \%$ \\
\cline { 2 - 4 } & Non-employed & 386 & $96.0 \%$ \\
\hline
\end{tabular}

\section{Data Collection Tools}

\subsection{Personal Information Form}

Personal Information Form was used to collect some demographic information of the children participating in the study. The form contains information on children's pre-school education, age, gender, education and working status of their parents.

\subsection{Primary School Readiness Scale}

Primary School Readiness Scale was developed by Canbulat and Kırıktaş (2016) by collecting data from 620 first-year pupils. The assessment tool consists of 33 items and 4 subdimensions: cognitive skills, affective skills, psychomotor skills and self-care skills. The scale was found to be a valid and reliable tool with an internal consistency coefficient of .991. The scale items consist of the following Likert type options: "(5) completely sufficient, (4) sufficient, (3) moderately sufficient, (2) partially sufficient and (1) not sufficient". The lowest score that can be obtained from the scale is 33 and the highest score is 165 . The high score obtained from the scale can be interpreted as high-level school readiness of the first-year students, whereas the low score indicates low-level school readiness. The sub-dimensions of the scale can be described as follows: Cognitive skills; cognitive skills that are expected to be acquired by the child in school readiness; affective skills; affective skills that are expected to be acquired by the child in school readiness; psychomotor skills: psychomotor skills that are expected to be acquired by the child in school readiness; self-care skills: self-care skills that are expected to be acquired by the child in school readiness. Before proceeding with the factor 
analysis of students' school readiness, the test known as Cronbach's Alpha test in the literature was performed to check the reliability of the measurement method. The reliability coefficient of the 33-item School Readiness Scale, which was applied to 402 students in total, was 0.991 (99.1\%). This level shows that the reliability of the measurement method is highly sufficient, and the compliance required for the analysis is ensured.

\section{Data Collection}

In the study, the measurement tool was applied to the children who started their first year in the fall semester of 2019-2020 academic year, by 15 teachers working in 3 different primary schools, in September. Necessary permissions were obtained before initiating the study and school administrators and teachers were met on a voluntary basis. The teachers evaluated the readiness of the children based on their observations about the children and filled the scale.

\subsection{Data Analysis}

The data were analyzed with SPSS 20 package program. The normality of the variables was checked by Kolmogorov-Smirnov and Shapiro Wilk tests. Using 0.05 significance level, if $\mathrm{p}<0,05$ the variables were assumed to be non-normally distributed. Non-parametric tests were used for variables that didn't show normal distribution. The results were also evaluated at 0.05 significance level. In order to determine the tests that are statistically appropriate to apply, the new dimensions obtained from the scores given to the questions were tested in terms of normality. The zero hypothesis, which assumes that the calculated dimensions show normal distribution, is rejected with $95 \%$ reliability according to Kolmogorov \& Simonov Test. Therefore, non-parametric methods were preferred for difference tests. The descriptive analysis was conducted to determine school readiness of the first-year pupils and the arithmetic means and standard deviations of the scores were calculated. Kruskal Wallis-H and Mann Whitney-U test were used to determine whether children's school readiness differed significantly in terms of pre-school education, gender, age, and educational and working status of their parents.

\section{Results}

Descriptive statistics related to the dimensions of the primary school readiness scale of the children participating in the study are given in Table 3 .

Table 2. Descriptive statistics

\begin{tabular}{|c|c|c|c|c|}
\hline & Minimum & Maximum & Mean & Standard Deviation \\
\hline Cognitive Skills & 17.00 & 85.00 & 67.7164 & 13.54439 \\
\hline Affective Skills & 8.00 & 40.00 & 32.2786 & 6.30259 \\
\hline Psychomotor Skills & 3.00 & 15.00 & 11.9204 & 2.53920 \\
\hline Self-Care Skills & 5.00 & 25.00 & 21.1169 & 3.91222 \\
\hline Number of Observations (N) & 402 & & & \\
\hline
\end{tabular}

Regarding primary school readiness levels of the children displayed in Table 2, it can be said that the averages are quite high. In other words, children are quite ready to start school in terms of cognitive, affective, psychomotor and self-care skills. The results of independent 
sample t-test and one-way analysis of variance (ANOVA) used to check whether these dimensions are affected by the related demographic variables are given below.

\section{According to Preschool Education}

Table 3. Means of the Dimensions according to Preschool Education Status

\begin{tabular}{|c|l|c|c|c|}
\hline Dimensions & \multicolumn{1}{|c|}{ Preschool Education } & N & Mean & Std. Deviation \\
\hline \multirow{2}{*}{ Cognitive Skills } & Had Preschool Education & 374 & 68.9733 & 12.53304 \\
\cline { 2 - 5 } & Didn't have Preschool Education & 28 & 50.9286 & 15.50610 \\
\hline \multirow{2}{*}{ Affective Skills } & Had Preschool Education & 374 & 32.7326 & 5.86425 \\
\cline { 2 - 5 } & Didn't have Preschool Education & 28 & 26.2143 & 8.59525 \\
\hline $\begin{array}{c}\text { Psychomotor } \\
\text { Skills }\end{array}$ & Had Preschool Education & 374 & 12.1043 & 2.40806 \\
\cline { 2 - 5 } & Didn't have Preschool Education & 28 & 9.4643 & 2.98741 \\
\hline \multirow{2}{*}{\begin{tabular}{c} 
Self-Care Skills \\
\cline { 2 - 5 }
\end{tabular}} & Had Preschool Education & 374 & 21.2861 & 3.68039 \\
\cline { 2 - 5 } & Didn't have Preschool Education & 28 & 18.8571 & 5.87344 \\
\hline
\end{tabular}

According to Table 3, it was observed that school readiness scores of the children who received pre-school education are higher than the children who did not. Mann Whitney-U test was used to determine whether this difference was significant.

Table 4. Mann Whitney-U Test Results According to Preschool Education

\begin{tabular}{|l|l|l|l|l|}
\hline & Cognitive Skills & Affective Skills & Psychomotor Skills & Self-Care Skills \\
\hline Mann-Whitney U & 1962.500 & 2742.000 & 2643.000 & 3865.500 \\
\hline Wilcoxon W & 2368.500 & 3148.000 & 3049.000 & 4271.500 \\
\hline Z & -5.567 & -4.246 & -4.509 & -2.401 \\
\hline p. & $.000^{*}$ & $.000^{* *}$ & .000 & $.016^{*}$ \\
\hline
\end{tabular}

$$
{ }^{*} \mathrm{p}<0.05 ; H_{0}: \mu_{1}=\mu_{2}
$$

Accordingly to Table 4 , it can be said that pre-school education is statistically significant on all sub-dimensions of readiness scale $(\mathrm{p}<0.05)$. Therefore, the children who receive preschool education are more ready to school. The results of the test analyzing whether the subscales of readiness scale differ significantly in terms of the gender are shown below;

\section{According to Gender}

Table 5. Means of the Dimensions according to Gender

\begin{tabular}{|c|c|c|c|c|}
\hline Dimensions & Gender & N & Mean & Std. Deviation \\
\hline \multirow{2}{*}{ Cognitive Skills } & Female & 199 & 68.5327 & 13.00884 \\
\cline { 2 - 4 } & Male & 203 & 66.9163 & 14.03559 \\
\hline \multirow{2}{*}{ Affective Skills } & Female & 199 & 32.9497 & 5.76628 \\
\cline { 2 - 4 } & Male & 203 & 31.6207 & 6.73685 \\
\hline \multirow{2}{*}{ Psychomotor Skills } & Female & 199 & 12.0402 & 2.40966 \\
\cline { 2 - 4 } & Male & 203 & 11.8030 & 2.66079 \\
\hline \multirow{2}{*}{ Self-Care Skills } & Female & 199 & 21.1658 & 3.82148 \\
\cline { 2 - 4 } & Male & 203 & 21.0690 & 4.00806 \\
\hline
\end{tabular}

Regarding the school readiness of children according to gender, it is seen that girls' school readiness score is higher than boys. Mann Whitney-U test was used to determine whether this difference seen in favor of girls constitutes a significant difference between genders. 
Table 1. Mann Whitney-U Test Results According to Gender

\begin{tabular}{|c|c|c|c|c|}
\hline & Cognitive Skills & Affective Skills & Psychomotor Skills & Self-Care Skills \\
\hline Mann-Whitney U & 18750.000 & 17857.000 & 19254.500 & 20000.000 \\
\hline Wilcoxon W & 39456.000 & 38563.000 & 39960.500 & 40706.000 \\
\hline Z & -1.254 & -2.030 & -.836 & -.177 \\
\hline p. & .210 & $.042^{*}$ & .403 & .859 \\
\hline
\end{tabular}

${ }^{*} p<0.05 ; H_{0}: \mu_{1}=\mu_{2}$

According to Table 6, it can be said that gender is effective on affective skills dimension of readiness scale $(\mathrm{p}<0.05)$, whereas it is ineffective on the other dimensions. In other words, the school readiness level of the girls differs significantly from boys in the affective dimension. The results of the Kruskal-Wallis $\mathrm{H}$ test analyzing the significance of the difference between the students' age groups' means for related dimensions are shown below.

\section{According to Age Groups}

Table 7. Means of the Dimensions according to Age Groups

\begin{tabular}{|c|c|c|c|c|}
\hline \multirow{2}{*}{ Dimensions } & Age Groups & $\mathrm{N}$ & Mean & Std. Deviation \\
\hline \multirow{3}{*}{ Cognitive Skills } & 6 years-old & 284 & 65.1127 & 13.00834 \\
\cline { 2 - 5 } & 7 years-old & 118 & 73.9831 & 12.78219 \\
\cline { 2 - 4 } & Overall & 402 & 67.7164 & 13.54439 \\
\hline \multirow{3}{*}{ Affective Skills } & 6 years-old & 284 & 30.9577 & 6.14072 \\
\cline { 2 - 5 } & 7 years-old & 118 & 35.4576 & 5.52329 \\
\cline { 2 - 5 } & Overall & 402 & 32.2786 & 6.30259 \\
\hline \multirow{3}{*}{ Psychomotor Skills } & 6 years-old & 284 & 11.3803 & 2.39621 \\
\cline { 2 - 5 } & 7 years-old & 118 & 13.2203 & 2.40774 \\
\hline \multirow{3}{*}{ Self-Care Skills } & Overall & 402 & 11.9204 & 2.53920 \\
\cline { 2 - 5 } & 6 years-old & 284 & 20.2887 & 4.01777 \\
\cline { 2 - 5 } & 7 years-old & 118 & 23.1102 & 2.78207 \\
\hline
\end{tabular}

Table 7 shows that, children's school readiness increases as their age increases. The significance of the difference between the scores was tested by Kruskal-Wallis test.

Table 8. Kruskal-Wallis H Test Results According to Age Groups

\begin{tabular}{|c|c|c|c|c|}
\hline & Cognitive Skills & Affective Skills & Psychomotor Skills & Self-Care Skills \\
\hline $\mathrm{X}^{2}$ & 43.039 & 49.265 & 52.520 & 50.191 \\
\hline S.d. & 1 & 1 & 1 & 1 \\
\hline p. & $.000^{*}$ & $.000^{*}$ & $.000^{*}$ & $.000^{*}$ \\
\hline
\end{tabular}

${ }^{*} p<0.05 ; H_{0}: \mu_{1}=\mu_{2}=\cdots \mu_{n}$

According to Table 8 , it can be said that the age factor is statistically significant on all subdimensions of readiness scale $(\mathrm{p}<0.05)$. Therefore, children's school readiness level significantly increases as their age increases. The results of the Kruskal-Wallis $\mathrm{H}$ test analyzing the effect of Mother's education and working status on relevant variables are shown below. 


\section{According to Mother's Education}

Table 9. Means of the Dimensions according to the Mother's Education

\begin{tabular}{|c|c|c|c|c|}
\hline Dimensions & Mother's Education & $\mathrm{N}$ & Mean & Std. Deviation \\
\hline \multirow{5}{*}{ Cognitive Skills } & Primary School & 79 & 61.2785 & 15.27352 \\
\hline & Secondary School & 88 & 66.7614 & 13.23961 \\
\hline & High School & 117 & 67.8376 & 12.80555 \\
\hline & University, Postgraduate & 118 & 72.6186 & 11.28642 \\
\hline & Overall & 402 & 67.7164 & 13.54439 \\
\hline \multirow{5}{*}{ Affective Skills } & Primary School & 79 & 29.1899 & 7.45254 \\
\hline & Secondary School & 88 & 32.0000 & 5.90149 \\
\hline & High School & 117 & 32.6068 & 5.92621 \\
\hline & University, Postgraduate & 118 & 34.2288 & 5.28732 \\
\hline & Overall & 402 & 32.2786 & 6.30259 \\
\hline \multirow{5}{*}{ Psychomotor Skills } & Primary School & 79 & 10.9873 & 2.81704 \\
\hline & Secondary School & 88 & 11.5114 & 2.50055 \\
\hline & High School & 117 & 12.1282 & 2.45138 \\
\hline & University, Postgraduate & 118 & 12.6441 & 2.21697 \\
\hline & Overall & 402 & 11.9204 & 2.53920 \\
\hline \multirow{5}{*}{ Self-Care Skills } & Primary School & 79 & 19.9114 & 4.83892 \\
\hline & Secondary School & 88 & 20.8750 & 3.97351 \\
\hline & High School & 117 & 21.1197 & 3.39412 \\
\hline & University, Postgraduate & 118 & 22.1017 & 3.41788 \\
\hline & Overall & 402 & 21.1169 & 3.91222 \\
\hline
\end{tabular}

Regarding school readiness according to mother's educational status, an increase was observed in children's school readiness scores as mothers' education level increases towards university and master's degree. The significance of the difference between the scores was tested by Kruskal-Wallis test.

Table 2. Kruskal-Wallis H Test Results According to the Mother's Education

\begin{tabular}{|c|c|c|c|c|}
\hline & Cognitive Skills & Affective Skills & Psychomotor Skills & Self-Care Skills \\
\hline $\mathrm{X}^{2}$ & 33.668 & 27.564 & 23.810 & 12.787 \\
\hline S.d. & 3 & 3 & 3 & 3 \\
\hline p. & $.000^{*}$ & $.000^{*}$ & $.000^{*}$ & $.005^{*}$ \\
\hline
\end{tabular}

${ }^{*} p<0.05 ; H_{0}: \mu_{1}=\mu_{2}=\cdots \mu_{n}$

According to Table 10, it can be said that the mother's education is statistically significant on all sub-dimensions of readiness scale $(\mathrm{p}<0.05)$. The results of the test analyzing the effect of mother's employment status on relevant variables are shown below; 


\section{According to Mother's Employment status}

Table 3. Means of the Dimensions according to the Mother's Employment status

\begin{tabular}{|c|c|c|c|c|}
\hline Dimensions & Mother's Employment & $\mathrm{N}$ & Mean & Std. Deviation \\
\hline \multirow{2}{*}{ Cognitive Skills } & Housewife & 254 & 66.7244 & 13.60869 \\
\cline { 2 - 4 } & Employed & 148 & 69.4189 & 13.30695 \\
\hline \multirow{2}{*}{ Affective Skills } & Housewife & 254 & 31.9449 & 6.39022 \\
\cline { 2 - 4 } & Employed & 148 & 32.8514 & 6.12829 \\
\hline \multirow{2}{*}{ Psychomotor Skills } & Housewife & 254 & 11.7520 & 2.61296 \\
\cline { 2 - 4 } & Employed & 148 & 12.2095 & 2.38833 \\
\hline \multirow{2}{*}{ Self-Care Skills } & Housewife & 254 & 21.0039 & 3.84121 \\
\cline { 2 - 4 } & Employed & 148 & 21.3108 & 4.03699 \\
\hline
\end{tabular}

As can be seen in Table 11, the school readiness level of the children with working mothers is higher. Mann Whitney-U test was used to determine whether this ratio makes a significant difference between the groups.

Table 4. Mann Whitney-U Test Results according to the Mother's Employment status

\begin{tabular}{|c|c|c|c|c|}
\hline & Cognitive Skills & Affective Skills & Psychomotor Skills & Self-Care Skills \\
\hline Mann-Whitney U & 16477.000 & 16903.000 & 16732.500 & 17585.500 \\
\hline Wilcoxon W & 48862.000 & 49288.000 & 49117.500 & 49970.500 \\
\hline Z & -2.081 & -1.701 & -1.894 & -1.119 \\
\hline p. & $.037 *$ & .089 & .058 & .263 \\
\hline
\end{tabular}

${ }^{*} \mathrm{p}<0.05 ; H_{0}: \mu_{1}=\mu_{2}$

Regarding Table 12, the zero-hypothesis claiming is rejected only in cognitive skills dimension at $95 \%$ confidence level $(\mathrm{p}<0.05)$. Therefore, it is not valid for the remaining dimensions. In other words, it is seen that children are significantly more ready to school in terms of cognitive skills dimension according to the working status of their mother. The results of the test analyzing the effects of father's education and working status on relevant variables are shown below;

\section{According to Father's Education}

Table 5. Means of the Dimensions according to the Father's Education

\begin{tabular}{|c|c|c|c|c|}
\hline \multirow{2}{*}{ Dimensions } & Father's Education & N & Mean & Std. Deviation \\
\hline \multirow{3}{*}{ Cognitive Skills } & Primary School & 35 & 59.4857 & 15.07700 \\
\cline { 2 - 4 } & Secondary School & 72 & 65.5417 & 14.39282 \\
\cline { 2 - 4 } & High School & 162 & 67.3210 & 13.39679 \\
\cline { 2 - 5 } & University, Postgraduate & 133 & 71.5414 & 11.53027 \\
\cline { 2 - 5 } & Overall & 402 & 67.7164 & 13.54439 \\
\hline \multirow{3}{*}{ Affective Skills } & Primary School & 35 & 28.8000 & 7.32763 \\
\cline { 2 - 5 } & Secondary School & 72 & 31.5139 & 6.69453 \\
\cline { 2 - 5 } & High School & 162 & 32.3580 & 6.19418 \\
\hline
\end{tabular}




\begin{tabular}{|c|c|c|c|c|}
\hline \multirow{4}{*}{ Psychomotor Skills } & University, Postgraduate & 133 & 33.5113 & 5.55635 \\
\cline { 2 - 4 } & Overall & 402 & 32.2786 & 6.30259 \\
\cline { 2 - 4 } & Primary School & 35 & 10.9429 & 3.07689 \\
\cline { 2 - 4 } & Secondary School & 72 & 11.0417 & 2.82562 \\
\cline { 2 - 4 } & High School & 162 & 12.0617 & 2.36877 \\
\cline { 2 - 4 } & University, Postgraduate & 133 & 12.4812 & 2.23472 \\
\cline { 2 - 5 } & Overall & 402 & 11.9204 & 2.53920 \\
\hline \multirow{3}{*}{ Self-Care Skills } & Primary School & 35 & 19.8286 & 4.72469 \\
\cline { 2 - 5 } & Secondary School & 72 & 20.6667 & 4.11113 \\
\cline { 2 - 5 } & High School & 162 & 21.0988 & 3.96132 \\
\cline { 2 - 5 } & University, Postgraduate & 133 & 21.7218 & 3.40533 \\
\cline { 2 - 5 } & Overall & 402 & 21.1169 & 3.91222 \\
\hline
\end{tabular}

Regarding school readiness according to father's educational status, an increase in children's school readiness scores was observed as fathers' education level increases. The significance of this difference between the scores was tested by Kruskal-Wallis test.

Table 6. Kruskal-Wallis H Test Results According to the Father's Education

\begin{tabular}{|c|c|c|c|c|}
\hline & Cognitive Skills & Affective Skills & Psychomotor Skills & Self-Care Skills \\
\hline $\mathrm{X}^{2}$ & 24.549 & 15.633 & 17.239 & 6.422 \\
\hline S.d. & 3 & 3 & 3 & 3 \\
\hline p. & $.000^{*}$ & $.001^{*}$ & $.001^{*}$ & .093 \\
\hline
\end{tabular}

*p $<0.05 ; H_{0}: \mu_{1}=\mu_{2}=\cdots \mu_{n}$

Regarding Table 18, the zero-hypothesis claiming that the difference between the group means is statistically insignificant, is rejected in cognitive skills, affective skills, and psychomotor skills dimensions at 95\% confidence level $(\mathrm{p}<0.05)$. However, a statistically significant difference was not found in terms of Self-Care Skills. As in the education level of the mothers, children's primary school readiness level increases as the education level of the fathers increases. Finally, the results of the test analyzing the effect of father's employment status on relevant variables are shown below;

\section{According to Father's Employment status}

Table 7. Means of the Dimensions according to the Father's Employment status

\begin{tabular}{|c|c|c|c|c|}
\hline Dimensions & Father's Employment & $\mathrm{N}$ & Mean & Std. Deviation \\
\hline \multirow{2}{*}{ Cognitive Skills } & Non-employed & 16 & 59.0000 & 19.33218 \\
\cline { 2 - 4 } & Employed & 386 & 68.0777 & 13.16150 \\
\hline \multirow{2}{*}{ Affective Skills } & Non-employed & 16 & 27.6250 & 8.90599 \\
\cline { 2 - 4 } & Employed & 386 & 32.4715 & 6.11113 \\
\hline \multirow{2}{*}{ Psychomotor Skills } & Non-employed & 16 & 9.9375 & 3.10846 \\
\cline { 2 - 4 } & Employed & 386 & 12.0026 & 2.48371 \\
\hline \multirow{2}{*}{ Self-Care Skills } & Non-employed & 16 & 18.1250 & 6.02080 \\
\cline { 2 - 4 } & Employed & 386 & 21.2409 & 3.76056 \\
\hline
\end{tabular}

As can be seen in Table 15, the school readiness levels of the children whose fathers are working are higher than the children whose fathers are not working. 
Table 16. Mann Whitney-U Test Results according to the Father's Employment status

\begin{tabular}{|c|c|c|c|c|}
\hline & Cognitive Skills & Affective Skills & Psychomotor Skills & Self-Care Skills \\
\hline Mann-Whitney U & 2145.000 & 2049.500 & 1823.000 & 2171.500 \\
\hline Wilcoxon W & 2281.000 & 2185.500 & 1959.000 & 2307.500 \\
\hline Z & -2.088 & -2.302 & -2.864 & -2.091 \\
\hline $\mathrm{p}$ & $.037^{*}$ & $.021^{*}$ & $.004^{*}$ & $.037^{*}$ \\
\hline${ }^{*} \mathrm{p}<0.05 ; H_{0}: \mu_{1}=\mu_{2}$
\end{tabular}

According to Table 16, it can be said that the father's employment status is statistically significant on all sub-dimensions of readiness scale $(p<0.05)$. In other words, the children whose father is working starts the school more readily.

\section{Discussion and Conclusion}

In this study, primary school readiness of 402 children was analyzed. According to the results of the study, the average scores of the children were found to be high. In similar researches, children's school readiness levels have also been found to be high (e.g., Akay \& Ceylan, 2018; Alakoç Pirpir et al., 2016; Erkan and Kırca, 2010). In this study, primary school readiness levels of the children were analyzed according to some variables and significant differences were observed. One of these results is that primary school readiness level of the children receiving pre-school education was significantly higher than the children who did not receive pre-school education. Similarly, in their research focusing the effect of preschool education on children's school readiness, Ercan and Kirka (2010) concluded that there was a significant difference in favor of children receiving pre-school education. Esaspehlivan (2006) examined the school readiness level of the children who have received pre-school education and who have not. As a result of the study, it was found that the school readiness level of the children who received pre-school education differed significantly from the children who did not receive pre-school education. Alakoç Pirpir et al. (2016) found that there was a significant difference in favor of the children receiving pre-school education in their research on school maturity of primary school first-year pupils. The conclusion that preschool education variable has a positive effect on children's primary school readiness and school maturity (e.g., Arı \& Özcan, 2014; Erkan, 2011; Polat \& Yavuz, 2016; Unutkan, 2003) supports the result of the present research. In this context, the Preschool Education Program (MoNE, 2013), which aims to support all developmental areas of the children and prepare them to the next level of education, namely primary education, can be considered to be effectively implemented in educational institutions.

Another variable that predicted the primary school readiness of the children was age. It was found that 7-year-old children's primary school readiness was significantly different than 6 -year-old ones $(\mathrm{p}<0.05)$. Similar studies have shown that children's school readiness increases as the age of starting primary school increases, (e.g, Akay \& Ceylan, 2017; Yoleri \& Tanış, 2014). On the other hand, in Arı and Özcan's study on the school maturity of firstyear pupils, it was concluded that although the increase in age has positively affected the school maturity of children, it did not make a significant difference. Progress occurs in all development areas with the child's biological age, which is also considered as an important factor in getting the child ready for primary school. 
Regarding the effect of gender of the child on primary school readiness, mean scores of girls were slightly higher than boys in cognitive, psychomotor and self-care skills, but a significant difference $(\mathrm{p}<0.05)$ was only seen in affective skills. In the study on primary school children. Yurdakavuştu (2012) concluded that girls' emotional intelligence and social skills levels were higher than boys. However, the review of the related studies showed that there was no significant difference according to gender due to the fact that girls' scores were only slightly higher than that of the boys (e.g., Arı \& Özcan, 2014; Cinkılıç, 2009; Erkan, 2011; Yoleri \& Tanış, 2014).

The education level of the parents is among the variables that make a significant difference. The study showed that primary school readiness scores increase as the education level of the parents increases. Williams (2002) concluded that school maturity level of the children increases as the education level of their parents increases. Researches showing that the increase in the education level of the parents positively affects children's school readiness, support this result (e.g., Alakoç Pirpir et al., 2016; Ar1 \& Özcan, 2014; Erkan \& Kırca, 2010; Martin, Ryan \& Brooks Gunn, 2010; Unutkan, 2003). It can be said that the child may be exposed to more educational support and interaction at home as the education level of the parents increases. Parents with higher levels of education may spend more time with their children, play games and be more responsive to their educational needs. Parents play a very important role in creating a literacy environment at home to support the child (Saracho, 2008).

The study also showed that the working status of the parents, which is an important factor in determining the socio-economic level of the family, is a variable that predicts the primary school readiness of the children. Primary school readiness level of the children whose father was working differed significantly in all dimensions compared to the children with nonworking father. On the other hand, it was observed that affective, psychomotor and self-care skills of the children whose mother were working were slightly higher compared to children whose mothers did not work, and a significant difference was found in cognitive skills scores. It can be said that the socio-economic level of the children whose parents are working is better. Related studies show that the decrease in the socio-economic status of the family causes the child to be disadvantaged in being ready for school (e.g., Jeon et al., 2014; Ramey \& Ramey, 2004).

As a result, in the study where school readiness of the children was examined, it was seen that the school readiness of the children was high and their readiness levels were affected by pre-school education, gender, age, education and working status of their parents. In order to increase children's primary school readiness, the followings are recommended: encouraging children to receive pre-school education, waiting for the development of maturity level with age, further supporting boys in terms of affective skills, supporting families to minimize the negative effects that may arise from the education and working conditions of the parents.

This research has expanded the scope of researches focusing on primary school readiness conducted in Turkey. But there were some limitations. It should be noted that primary school readiness of first-year pupils may vary in Turkey due to individual and cultural differences of the children. The study was limited to 402 children. It should be considered that in different regions of Turkey, different variables may affect children's development levels, as well as their primary school readiness levels. Therefore, it is important to work with bigger and larger 
samples in the future and include different variables that may be effective in the primary school readiness.

\section{References}

Akbağ, M. (2007). Gelişim psikolojisi kavramlarına giriş: Kavramlar, ilkeler, dönemler. M. E. Deniz (Ed.), Eğitim psikolojisi, (ss. 27-54) içinde. Ankara: Maya Akademi.

Alakoç Pirpir, D., Soydan, S., \& Angın, E. (2016). Birinci sınıf öğrencilerinin okul olgunluk düzeylerini yordayıc bazı değişkenler. Pegem Atıf İndeksi, 489-504.

Baştuğ, M., \& Kurnaz, A. (2013). Birinci sınıfa hazır olmaya ilişkin öğretmen beklentileri. International Symposium on Changes and New Trends in Education Sempozyumu'nda sunulmuş bildiri, Necmettin Erbakan Üniversitesi, Konya.

Bütün Ayhan, A. ve Aral, N. (2007). Bracken temel kavram ölçeği-gözden geçirilmiş formunun altı yaş çocukları için uyarlama çalışması. Hacettepe Üniversitesi Eğitim Fakültesi Dergisi, 32, 42-51.

Britto, P. R. (2012). School readiness and transitions. New York: Education Section Programme Division, UNICEF. [Online]: Retrived on 10 Octaber 2019, at URL: https://www.unicef.org/publications/files/CFS_School_Readiness_E_web.pdf

Canbulat, A. N. K. ve Yıldızbaş, F. (2014). Okul öncesi ve sınıf öğretmenlerinin 60-72 aylık çocukların okula hazır bulunuşluklarına ilişkin görüşleri. Abant İzzet Baysal Üniversitesi Eğitim Fakültesi Dergisi, 14(1), 33-50.

Cinkılıç, H. (2009). Okul öncesi eğitimin ilköğretim birinci sınıf öğrencilerinin okul olgunluğuna etkisinin incelenmesi (Yüksek Lisans Tezi). Selçuk Üniversitesi, Konya.

Dinç, B.(2013).Okulöncesi eğitimden ilköğretime geçiş ve okul olgunluğu. F. Alisinanoğlu (Ed.). Illkögretime hazırlık ve ilköğretim programları, (ss.90-117). Ankara: Pegem Akademi Yayınc1lık.

Erkan, S. (2011). Farklı sosyoekonomik düzeydeki ilköğretim birinci sınıf öğrencilerinin okula hazır bulunuşluklarının incelenmesi. Hacettepe Üniversitesi Eğitim Fakültesi Dergisi, 40, 186-197.

Erkan, S. ve Kırca, A. (2010). Okul öncesi eğitimin ilköğretim birinci sınıf öğrencilerinin okula hazır bulunuşluklarına etkisinin incelenmesi. Hacettepe Üniversitesi Eğitim Fakültesi Dergisi, 38, 94106.

Esaspehlivan, M. (2006). Okul öncesi eğitim kurumuna gitmemiş 78 ve 68 aylık çocukların okula hazırbulunuşluklarının karşılaştırılması (Yüksek Lisans Tezi). Marmara Üniversitesi, İstanbul.

Ferguson, H. B., Bovaird, S., \& Mueller, M. P. (2007). The impact of poverty on educational outcomes for children. Podiatry Child Health, 12(8), 701-706.

Gündüz, F., ve Çalışkan, M. (2013). 60-66, 66-72, 72-84 aylık çocukların okul olgunluk ve okuma yazma becerilerini kazanma düzeylerinin incelenmesi. Turkish Studies, 8(8), 379-398.

Isaacs, J. B. ve Magnuson, K. (2011). Income and education as predictors of children's school readiness (Washington, DC: Brookings Institution). 19 Kasım 2019 tarihinde http://www.brookings.edu/ /media/files/rc/reports/2011/1214_school_readiness_isaacs/1214_scho ol_readiness_isaacs.pdf adresinden erişilmiştir.

Iş1k, A. D., Akosmanoğlu, E. ve Bilir, A. (2015). Socio-cultural factors effecting first grade primary school students' reading success. Elementary Education Online, 14(4), 1327-1340. 
Jeon, L., Cynthia, B. K. ve Eunhye, H. (2014). Family and neighborhood disadvantage, home environment, and children's school readiness. Journal of Family Psychology, 28(5), 718-727.

Koçyığıt, S., \& Saban, A. (2014). Birinci sınıf öğretmenlerinin ve ebeveynlerin görüşlerine göre okula hazır bulunuşluk. Kuramsal Ë̆itimbilim Dergisi, 7(3), 322-341.

Magnuson, K. A., Meyers, M. K., Ruhm, C. J. ve Waldfogel, J. (2004). Inequality in preschool education and school readiness. American Educational Research Journal, 41(1), 115-157.

Martin, A., Ryan, R. M. ve Brooks-Gunn, J. (2010). When fathers' supportiveness matters most: Maternal and paternal parenting and children's school readiness. Journal of Family Psychology, 24(2), 145-155.

MEB (İlköğretim kurumları yönetmeliğinde değişiklik yapılmasına dair yönetmelik). (2012). 22.11.2019 tarihinde web:www.resmigazete.gov.tr adresinden alınmıştır.

MEB (İlköğretim kurumları yönetmeliğinde değişiklik yapılmasına dair yönetmelik). (2019). 22.11.2019 tarihinde web:www.resmigazete.gov.tr adresinden alınmıştır.

MEB. (2013). Okul öncesi eğitim programı. Ankara: MEB Yayınları.

Noel, A.M. (2010). Perceptions of School Readiness in One Queensland Primary School. Australasian Journal of Early Childhood, 35(2), 28-35.

Oktay A., ve Unutkan Ö.P. (2005). İlköğretime hazır oluş ve okul öncesi eğitimle ilköğretimin karşılaştırılması. Müzeyyen Sevinç (Ed.), Erken çocuklukta gelişim ve eğitimde yeni yaklaşımlar, (ss. 145-155). İstanbul: Morpa Kültür Yayınları.

Öztürk, E. ve Uysal, K. (2013). İlkokul 1. sınıf öğrencilerinin okuma-yazma süreçlerinin takvim yaş1 yönünden karşılaştırılması. Turkish Studies, 8(8), 1041-1054.

Polat, Ö., \& Yavuz, E. A. (2016). The relationship between the duration of preschool education and primary school readiness. Childhood Education, 92(5), 396-404.

Ramey, C. T. ve Ramey, S. L. (2004). Early learning and school readiness: Can early intervention make a difference? Merrill-Palmer Quarterly, 50(4), 471-491.

Saracho, O. N. (2008). A literacy program for fathers: A case study, department of curriculum and instruction. Early Childhood Education Journal, 35, 351-356.

Stacks. A.M. \&Oshio,T (2009). Disorganize data chmentand social skills as indicators of Head Start children's school readiness skills. Attachment \& Human Development. 11(2), 143-164.

Umek, L. M., Kranjc, S., Fekonja, U., \& Bajc, K. (2008). The effect of preschool on children's school readiness. Early Child Development and Care, 178(6), 569-588. doi:10.1080/03004430600851280

Unutkan, Ö. P. (2003). Marmara İlköğretim Hazır Oluş Ölçeğinin Geliştirilmesi ve Standardizasyonu (Doktora Tezi). Marmara Üniversitesi, İstanbul.

Vandell, D.L., Nenide, L., ve Winkle, S.J.V. (2006). Peer relationships in early childhood. In McCartney, K., \& Philips, D. (Eds.), Blackwell handbook of early childhood development (pp. 455- 470). Malden, MA: Blackwell.

Yavuzer, H. (2010). Ana-baba ve çocuk. Remzi Kitabevi, 21. Basım, İstanbul.

Yazıcı, Z. (2002). Almanya ve Türkiye'de anaokuluna devam eden 60-76 aylar arasindaki türk çocuklarının dil gelişimi ile okuma olgunluğu arasındaki iliş̧kinin incelenmesi (Yüksek Lisans Tezi). Gazi Üniversitesi, Ankara. 
Yoleri, S. ve Tanış, H. M. (2014). İlkokul birinci sınıf öğrencilerinin okula uyum düzeylerini etkileyen değişkenlerin incelenmesi. Karabük Üniversitesi Sosyal Bilimler Enstitüsü Dergisi, 4(2), 130-141.

Yurdakavuştu, Y. (2012). İlkögretim ögrencilerinde duygusal zekâ ve sosyal beceri düzeyleri (Doktora Tezi). Dokuz Eylül Üniversitesi, Eğitim Bilimleri Enstitüsü, İzmir.

Yörükoğlu, A. (1993). Çocuk ruh sağglığı. İstanbul: Özgür Yayın Dağıtım. 